\title{
Operation Varsity Blues: Disguising the legal capital exchanges and white property interests in athletic admissions
}

\author{
Kirsten Hextrum
}

University of Oklahoma/ United States

\begin{abstract}
"Operation Varsity Blues" (OVB) indicted coaches and administrators from eight universities for accepting bribes in exchange for admitting fraudulent athletes. As part of the conspiracy parents paid university officials to admit students with little-to-no sport experience as college athletes. Court filings in the case contrasted OVB to the legal process of athletic recruitment and admission in which universities set different criteria to admit those with athletic talent (Smith, 2019a). This conceptual article cautions against such a contrast. Using Harris' (1993) whiteness as property, Bourdieu's (2011) capital exchange theory, and findings from my research into athletic recruitment and admission, I examine how OVB closely resembles current athletic admissions practices that provide a legal pathway to college that privileges white, elite communities.
\end{abstract}

Keywords: Operation Varsity Blues; whiteness theory; college admission; college athletics; cultural capital

In March 2019 fifty individuals were indicted in "Operation Varsity Blues" (OVB), a college admission conspiracy led by Rick Singer (Rosen et al., 2019a). In the conspiracy Singer bribed university administrators and coaches to admit students with little-to-no sport experience as college athletes (Smith, 2019a). The indictments claim defendants violated three federal laws - mail fraud, bribery, and racketeering - to secure college admission (Rosen et al., 2019a). Court filings depict Singer and his clients as corrupting a fair system of college admission by directly paying for college 
access (Rosen et al. 2019a; Smith, 2019a). While 22 parents were indicted, Singer admitted his scheme supported over 800 parents (Smith, 2019a). Those indicted include celebrities, wealthy bankers, and chief executives which drew much public interest and press attention to the scandal.

In 2018 and 2019 I published a series of original research articles on athletic admissions. My findings challenged the existing notion that exceptional athletic admission primarily support low-income men of color. Instead, I documented how athletic admissions are designed to favor those from white, middle- and upper-class communities (Hextrum, 2018a, 2018b, 2019). As one of a few scholars who study college athletic admissions (other notable studies include: Eckstein, 2017; Shulman \& Bowen, 2001; Smith, 2011) reporters contacted me for comment shortly after the Court released the OVB indictments. Most asked if I found instances of fraud or bribery in my studies of athletic admissions. I said "no" and instead described the similarities between my findings and Singer's actions (e.g., Alexander \& Steverman, 2019; Frances \& Krantz, 2019; Lartey, 2019). I attempted to reframe reporters' attention to how Singer's scheme is reflective of rather than a deviant detour from legal athletic admission practices.

In this conceptual article, I explore the logics and evidence behind my media comments that OVB resembles legal athletic admissions. To support my argument, I use evidence from two theoretical frameworks, Cheryl Harris' (1993) whiteness as property and Pierre Bourdieu's (2011) capital exchange; OVB legal documents; and my published studies into athletic recruitment and admission (Hextrum, 2018a, 2018b, 2019). I explain how Singer's actions are criminal under current law because college admissions disallow bribery, or what Bourdieu (2011) refers to as direct capital exchanges. Instead, legal athletic admissions permit indirect capital exchanges, or communal investments in an athlete to develop the social, physical and cultural capital needed for college recruitment. Current athletic admission practices also support what Harris (1993) refers to as whiteness as modern property by designing recruitment and entrance criteria that favor whites' historic accumulation of immaterial and material benefits across a range of institutions. In revealing how legal athletic admissions rely upon indirect capital exchange and whiteness as modern property I contend that the current process ensures that those from white, middleclass communities have greater access than lower-income communities of color to college via sport. I conclude with reform suggestions to limit both illegal and legal capital exchanges in athletic admissions.

\section{WHITENESS AND CAPITAL EXCHANGE}

Harris (1993) positioned college admissions as a central feature to maintain whiteness across all facets of U.S. life. Harris (1993) defined whiteness as a legally protected immaterial and material propertied resource available to some and denied to others. Whiteness is predicated upon a historical wedding of racial identity, legal rights, and economic exploitation (Harris, 1993). Historically, property claims like who was enslaved (African peoples), whose land claims went unrecognized (Native peoples), and who could profit from property (Whites) were filtered through and codified white supremacy (Harris, 1993). American colonists justified enslavement and 
colonization - in obvious contrast to their republican ideals of individual rights and liberties for all men - through a white supremacist ideology that positioned Whites as inherently superior to all other races (Harris 1993; Mills 1997, 2003). White supremacy eased the contradictions inherent in the nation's founding by stating nature "not man, not power, not violence" created the "degraded status" for Blacks and Native Americans (Harris, 1993, p. 1745). In reality, law not nature created a system of whiteness as status property that ensured and protected white superiority across all U.S. institutions (Harris, 1993). This form of whiteness as status property became "institutionalized privileges" for Whites across every facet of U.S. life (Harris, 1993, p. 1777). In so doing, Whites' greater access "became part of the settled expectations of Whites - a product of the unalterable origin bargain" enabling them to accumulate social, political, and economic benefits at the expense of people of color (Harris, 1993, p. 1777).

While the civil rights era ended government sponsored status property like overt segregation, it also relieved the state of any responsibility for fixing racism (Harris, 1993). Under modern property laws Whites became innocent from racism's origins and not subjected to property loss (Harris, 1993). To prove her point, Harris (1993) examined how the Court evaluated school desegregation and affirmative action cases based upon the potential harm to Whites instead of the potential justice these programs could bring to people of color. The resulting case precedents left intact the benefits Whites accrued under status property including a college admission system that elevated and rewarded whiteness (e.g., DiAngelo, 2011; Gusa, 2010; Harris, 1993; Mills, 2003). Harris (1993) offers an important caveat to modern whiteness by stating that the law does not guarantee greater access to all Whites in all circumstances. Poor Whites, in particular, are marginalized through capitalist exploitation. But, legal conflations of property and whiteness grant all Whites the immaterial benefits of association with the dominant race.

Whiteness as property illuminates how laws protect white power accumulation. Yet laws alone cannot account for the pervasiveness of white supremacy. Power relations are also emergent and rely upon individuals to (re)enact relations of domination intergenerationally (Bourdieu, 1978, 2011; Bourdieu \& Passeron, 1977). Bourdieu's interrelated theories of cultural reproduction (Bourdieu \& Passeron,1977) and capital exchange (2011) center schools as the vessel through which elite groups must activate and defend their status.

Bourdieu (2011) defines capital as symbolic and material resources that are exchanged for greater status. Cultural reproduction formulates how ruling groups control society not only by economic and political domination but also by defining what is culturally valued (Bourdieu \& Passeron, 1977). Through a lifetime of interacting with various institutions, individuals develop a habitus or the embodiment of cultural characteristics which are shaped by one's social position and shapes one's access to capital (Bourdieu, 1978). Schools are legitimating institutions that establish "conversion rates" between cultural characteristics and economic capital (Bourdieu \& Passeron, 1977, p. 50). College admission transforms one's habitus into "cultural competence" which offers "conventional, constant" "value" in the form of academic qualifications (Bourdieu \& Passeron, 1977, p. 50). Reproduction is obscured because the conversion is not guaranteed (Bourdieu, 2011). Direct and guaranteed forms of 
capital exchange are not permitted in democracies because they are visible and easily scrutinized (Bourdieu, 2011). Applying Bourdieusian logics to OVB reveals why Singer and his clients were prosecuted: they relied upon direct capital exchange for guaranteed college admission.

Harris (1993) identifies four modes through which whiteness functions as property: disposition; rights to use and enjoyments; reputation; and the absolute right to exclude. In this conceptual article, I correspond each mode to Bourdieu's capital theories to demonstrate how legal athletic recruitment protects the propertied interests of whiteness. Disposition refers to the immaterial form of whiteness, which is inseparable from your personhood, cannot be transferred to others, and accumulates benefits to the beholder (Harris, 1993). I correspond disposition to physical capital to examine how athletic talent is an accruable form of protected property more prevalent in white, middle-class communities. Rights to use and enjoyment refers to how whiteness is more than an embodied identity, it is an experience to be used and relished. I explore how Whites protect and defend their exclusive access to enjoy certain sport forms and enhance opportunities to develop physical capital. Reputation refers to how whiteness is an exchangeable and legally protected resource. Being legible as White affords one the potential for greater access to schools, jobs, political participation, etc. (DiAngelo, 2011; Gusa, 2010; Harris, 1993; Katznelson, 2005; Mills, 1997, 2003). Reputation corresponds to social capital in that one's whiteness offers them exclusive membership to an elite group (Whites). I describe how Whites forge relationships amongst themselves to secure greater access for one another through athletic recruitment. Finally, the absolute right to exclude refers to the "nucleus" of property and whiteness (Harris, 1993, p. 1714). Bourdieu's vision of schools as legitimating institutions assumes that educational institutions retain the power to exclude. In combining Harris's and Bourdieu's theories I demonstrate how college athletics functions as a legitimating institution through which individuals use their economic, social, and cultural capital to develop physical capital to exchange for college admission. The property interests of Whites are supported as definitions of merit, benefiting those from white, middle-class communities.

\section{EXCEPTIONAL ADMISSION PRACTICES FOR ATHLETES}

The National Collegiate Athletic Administration (NCAA) is a non-profit and statebacked institution that regulates U.S. college sports. NCAA regulations are grounded in amateurism defined as sport for pleasure not for profit (NCAA, 2017). In the $19^{\text {th }}$ century the white British ruling class invented amateurism to prevent the working class from athletic competition (Llewellyn \& Gleaves, 2014). Through controlling a cultural form, in this case sports, elites dictated the terms of acceptable behavior, membership, and access (Bourdieu, 1978). Amateurism expanded beyond Britain and was adopted by the NCAA and the Olympics, both of which banned athletes who exchanged their athleticism for payment (Llewellyn \& Gleaves, 2014).

Throughout the $20^{\text {th }}$ century American universities cultivated consumer markets around men's football and basketball which changed the racial and economic profiles of college athletes (Smith, 2011). The exploding revenue potential for men's football and basketball pushed university leaders to modify amateurism by permitting special 
admission and scholarships in exchange for athletic talent (Smith, 2011). While these rule changes expanded the recruitment pool to working-class White athletes, college sports retained overt racial segregation tactics to keep sports white well into the $1960 \mathrm{~s}$ (Martin, 2010). Student activism coupled with several high-profile matches in which integrated teams defeated all-white teams slowly eroded overt segregation (Martin, 2010). Donnor (2005) applied Derrick Bell's interest-convergence principle- that greater rights for people of color only come if those rights are controlled by and are in the interest of Whites - to athletic admissions to argue that universities began to admit Black athletes not for racial justice but to enhance universities' athletic programs and national profiles (Donnor, 2005).

The partial inclusion of Black athletes did not end but instead entrenched racism in college sports by creating ever-novel means of reproduction (Donnor, 2005). For instance, Black men are concentrated in revenue-producing sports and must overperform their athleticism to receive admission (Coakley, 2015; Hawkins, 2010; Washington \& Karen, 2001). In 2017, 44.2\% of Division-I football and 53\% of basketball athletes were Black (Lapchick, 2018) whereas only $9 \%$ of students at Division-I institutions were Black (NCAA, 2018). Despite Black men's overrepresentation in revenue sports, Whites remain the decision-makers and beneficiaries of college sports as most coaches $(86.5 \%)$, athletic directors $(86.1 \%)$, and university presidents (89.2\%) are White (Lapchick, 2018). Whites have used their control of college sports to strip the rights and benefits from athletes. The NCAA has 700 rules related to amateurism and recruitment (NCAA, 2017). College athletes cannot: associate with professional sport teams; have an agent; accept extra benefits from anyone associated with college sport; or receive compensation beyond expenses (NCAA, 2017). Many characterize these amateur regulations as racially exploitative by enabling Whites to profit from the unpaid labor of mostly low-income Black men (e.g., Donnor, 2005; Hawkins, 2010; Sack, \& Staurowsky 1998; Smith, 2011).

In response to legal challenges and athlete activism, the NCAA once again modified its amateur regulations. In October 2019 the NCAA voted to permit athletes to "benefit from the use of their name, image, and likeness in a manner consistent with the collegiate model" signifying a potential crack in long-standing amateur standards (Osburn, 2019, para. 1). As of publication, the NCAA had yet to adopt specific rule changes but reiterated that all forthcoming changes will ensure athletes cannot become "employees of the university" (Osburn, 2019, para. 3). Without employee status athletes have no right to guaranteed payment nor legal protections like workers compensation. Thus, these changes resemble interest-convergence by granting some concessions to athletes all the while protecting the existing exploitive model of collegiate athletics.

The proposed amateur changes do not modify admission standards. The NCAA permits universities to develop their own admissions policies so long as the policy adheres to the NCAA's academic minimum (NCAA, 2017). Many universities use separate athletic admission processes with lower academic standards (Shulman \& Bowen, 2001; Smith, 2011). Administrators justify these lower standards as necessary to recruit the best talent for their revenue-generating football and basketball programs (Shulman \& Bowen, 2001; Smith, 2011). But revenue generating sports are only two of forty college sports. Further, the majority of athletes come from 
communities already-aligned with college-going prospects, namely they are white, middle-class, and not first-generation college students. White women occupy $71.7 \%$ and White men occupy $63.7 \%$ of the NCAA's sports (Lapchick, 2018). The NCAA does not publish data on athletes' class backgrounds but they did release a study on the percentage of first-generation college students, an indicator of class (Stephens, Hamedani, \& Destin, 2014). In 2015, 14\% of athletes were first generation college students (NCAA, 2016). Sports affiliated with pay-to-play youth opportunities had the lowest rates of first-generation college students: lacrosse (2\%), field hockey (3\%), rowing $(4 \%)$, gymnastics $(7 \%)$, swimming $(7.5 \%)$, golf $(10.5 \%)$, and tennis $(10.5 \%)$ (Farrey, 2017). Current demographics suggest that white, middle-class people, more so than lower-income and racialized minorities, benefit from amateur athletics by receiving admission advantages in non-exploited sports. In this way, amateur athletics retains its elitist origins by protecting a special route to college for white, middleclass athletes.

\section{CONCEPTUAL APPROACH}

Four years prior to the OVB indictment I conducted life-history interviews with 47 Division-I college athletes in non-revenue sports (rowing and track \& field) at Coastal-U (university pseudonym). My original study examined how power relationships frame an athletic pathway to higher education. I selected Coastal-U because it is a highly selective, public, research-1 university and member of the NCAA's Division-I, power-five conference, placing it among the most infamous and competitive college sports programs. Across several publications, I used my findings from these interviews to outline an exceptional pathway to college via sport that privileges white, elite communities (Hextrum, 2018a, 2018b, 2019).

For this article, I summarize and apply my findings from past studies on college athletic recruitment to the details of the OVB case. Previous studies into athletic admissions have revealed the historic contexts of exceptional admission practices of athletic admissions (e.g., Smith, 2011), the demographic trends of who most benefits from these policies (e.g., Shulman \& Bowen, 2001), and the athlete narratives of how they navigate recruitment (e.g., Eckstein, 2017; Hextrum, 2018a, 2018b, 2019). The FBI evidence collected to prosecute OVB offers rare insights into how coaches and administrators conceptualize and conduct athletic admissions. The documents outline how athletic admissions typically function and point to moments where Singer's conspiracy corrupted these processes. As of publication, 33 documents were publicly available. The documents totaled 576 pages and included FBI affidavits recounting the investigation (e.g., Smith, 2019a), indictments listing the charges (e.g., Rosen et al., 2019a), and cooperation and plea agreements. For this article, I deductively coded (Ravitch \& Carl, 2016; Strauss \& Corbin, 1998) OVB court documents with whiteness as property (Harris, 1993), capital exchange (Bourdieu, 2011), and my previous research codes (see Hextrum, 2019 for codebook). After I completed deductive coding, I used axial coding (Strauss \& Corbin, 1998) to group the descriptive codes. Here, I became the "primary instrument" of analysis (Ravitch \& Carl, 2016, p. 261) as I identified higher order themes (Strauss \& Corbin, 1998). I use 
these themes as evidence to support my argument that Singer's actions run parallel to rather than contrast with legal athletic admission practices.

\section{ATHLETIC ADMISSIONS: ILLEGAL VERSUS LEGAL CAPITAL EXCHANGE}

In 2011 Singer morphed his legal advising business into an illegal enterprise. On FBI wiretap Singer explained how he guaranteed admission through his "side door" plot. Singer targeted athletic admissions because "admission prospects of recruited athletes are significantly higher than those of non-recruited athletes within similar grades and test scores" (Smith, 2019b, p. 2). Singer developed relationships with college coaches and administrators who oversaw athletic admissions and paid his contacts to "designate certain applicants as recruited athletes...thereby facilitating the applicants' admission" (Smith, 2019a, p. 2). Singer and his contacts charged different rates depending on the institution. Admission to USC cost $\$ 250,000$ whereas admission to Georgetown cost $\$ 400,000$ (Smith, 2019a). Between 2011-2018, Singer accepted \$25 million from families in exchange for admission (Smith, 2019a). Federal prosecutors criminalized Singer's side door scheme by charging him with three crimes: mail fraud, bribery, and racketeering (Smith, 2019a).

Court filings contrast Singer's side door scheme to legal special athletic admission. FBI Agent Laura Smith (2019a), who ran OVB and compiled the prosecutable evidence for federal attorneys, stated that athletic admissions permit coaches to admit athletes who would not otherwise be admitted to the university but are "important assets" who contribute to the "composition of undergraduate classes" (Smith, 2019a, p. 9). Smith positioned Singer's actions as corrupting the legal process of athletic admission by admitting illegitimate athletes who would not otherwise be admitted to the university albeit for direct capital exchanges. By applying my findings from research into the legal process of athletic admission I argue that Singer's scheme closely parallels how legitimate athletes access universities through exceptional admissions. In so doing, I question how universities define legitimate athletes and how capital is exchanged within special admissions.

\section{Physical Capital: Athletic Talent}

OVB documents revealed that admission administrator(s) scrutinized the applicant's academic performance but deferred to athletic departments to judge athletic performance (Rosen et al., 2019a; Smith, 2019a, 2019b). Court filings against Michael Center, a tennis coach at the University of Texas explained how "admission officers are deferential to the coaches' judgment about applicants' athletic abilities" (Smith, 2019b, p. 2). Without uniform or transparent admission standards, athletes create dossiers full of pliable criteria like photos, resumes, and references which are not solicited from universities but if presented can increased one's odds of recruitment (Hextrum, 2018a, 2018b). Through his network, Singer learned how to create dossiers and pose his clients as elite athletes - exaggerating or lying about their athletic credentials - in ways that appealed to athletic departments. The fake athletic 
admission materials used in OVB mirror the physical capital desired in athletic admission.

Access to resources to develop physical capital remain unequally distributed across race and socioeconomic status. Mid- $20^{\text {th }}$ century government policies such as redlining, federal housing loans, and mortgage discrimination created suburbs and offered affordable homes to White people while simultaneously restricting and denying these benefits to people of color (Katznelson, 2005; Lassiter, 2012; Schneider, 2008). Today, White people are more likely to grow up and live within majority-white communities than people of color (DiAngelo, 2011). Sports have become a central feature of suburban communities to demark middle-class standing (Andrews, 1999; DeLuca \& Andrews, 2016; Messner, 2009). A national survey of youth sports participation found that White, suburban youth are the most likely group to participate in sports as suburban areas have more athletic offerings than urban or rural areas (Sabo \& Veliz, 2008).

Affluent suburban communities protect their class and race privilege by creating cultural practices that rely upon material and immaterial characteristics (Andrews, 1999; Coakley, 2015; DeLuca \& Andrews, 2016; Messner, 2009). Here, I argue that the physical capital valued by university admissions maps onto the dispositions (Harris, 1993) accrued within white, middle-class communities. White, elite communities have greater opportunities to develop and nurture physical capital through their rights to use and enjoyment (Harris, 1993). The legal documents revealed that Singer helped clients "fabricat[e] athletic 'profiles' containing falsified athletic credentials" like "fake honors," membership on "elite athletic teams," and "staged photographs" (Rosen et al., 2019b) all in an effort to mirror the physical capital available in white, elite communities. In Hextrum (2018b) I identified three aspects of physical capital - time, private clubs, and camps - and all of which required capital investment. Court documents indicated that Singer used these same aspects to fake physical capital.

\section{Time}

Bourdieu (1978) equates time to economic capital. Developing physical capital requires time invested in sport instead of other activities like employment or household responsibilities (Shilling, 1991). Singer's fake athletic resumes listed large time commitments to signify his clients' physical capital. In one case, Singer posed the Henriquezes' daughter as a tennis recruit by emphasizing her time investment: "For years I have spent three-four hours a day grinding out on and off court workouts with the hopes of becoming successful enough to play college tennis especially at Georgetown," (Smith, 2019a, p. 51). Similarly, Singer wrote an admission essay for Robert Zangrillo's daughter stating that she rowed "an average of 44 hours per week for 15 weeks per year" (Smith, 2019a, p. 119).

My research also indicated that universities equated time commitment with merit. In Hextrum (2018a) I documented how 79\% of recruited athletes played sports year-round by high school and 36\% practiced twice-per-day (p. 364). The average time commitment (excluding travel and competition) was 17.1 hours per week. During competition season time commitments expanded to 40 hours per week 
(Hextrum, 2018a). I found that those pursuing admission to college via athletics could dedicate time to sport because they did not have employment or domestic responsibilities (Hextrum, 2018b). The NCAA places no limits on how much time an athlete spends on their sport prior to college. Time, therefore, is an unregulated resource that families and individuals can spend on developing athletic talent. Those with greater access to time have greater access to developing the physical capital desired by universities for athletic admission.

\section{Private Clubs}

Another marker of athletic merit valued by universities is athletes' affiliation with private clubs. OVB used private clubs to demonstrate athletic merit. Six profiles used as evidence in the FBI cases forged membership at private clubs in volleyball, tennis, rowing, soccer, and water polo.

White, suburban communities are more likely to have exclusive, elite youth athletic clubs than rural and urban areas (Sabo \& Veliz, 2008). Eckstein (2017) studied how the rise of pay-to-play youth sport clubs impact athletic admissions. He examined sports with athletic college admissions markets (soccer and field hockey) and sports without (figure skating and ultimate frisbee). He found that pay-for club opportunities proliferate in sports with the promise of college admissions as parents invest in sports to increase their children's odds of recruitment. Similarly, I found that $77 \%$ of recruited athletes used private clubs to develop their physical capital (Hextrum 2019, p. 12). Private clubs required greater financial and time contributions from families, including paying for travel costs, uniforms, club, and equipment. For instance, the average membership for U.S. junior rowing programs was $\$ 2,674$ per year (in 2016 dollars). I also found that track \& field athletes increased their recruitment prospects by pursuing field events (i.e. pole vault, triple jump, and discus) which require technical expertise not often available through high school or club teams. Instead, athletes who could pay for private coaching (ranging from $\$ 50$ 100/hour) could quickly excel in these events (Hextrum, 2019). The NCAA limits whether athletes receive compensation but does not limit how much money one spends on accruing physical capital (Hextrum, 2018b).

\section{Camps}

Youth also develop physical capital through pay-to-play camps (Eckstein, 2017; Hextrum, 2018b). On FBI wiretap, Singer told his client William McGlashan Jr. that his son could pass as a football player by listing he went to a kicker development camp. Singer explained that the position of kicker did not require direct experience and the skills required could be learned through attending a camp (Smith, 2019a). In another instance, Singer helped Devin Sloane submit a fake water polo profile for his son who attended a school without a water polo team. Donna Heinel, one of Singer's insiders at USC, assisted Sloane and suggested that his son claim he played for the Italian junior national team. Heinel stated that through international competition Sloane's son caught the attention of and later made contact with the USC water polo coach. USC's director of admissions thanked Heinel for providing this additional 
context. Sloane's son received admission to USC (Rosen et al., 2019c). USC validated these resume lines by admitting McGlashan's son as a football recruit and Devin Sloane's son as a water polo recruit (Rosen et al., 2019d).

In Hextrum (2018b) I described how attending pay-to-play athletic camps are used by recruited athletes to prove their physical capital. I found that $47 \%$ of recruited athletes used their experience at a national-team affiliated camp during recruitment. The camps vary by age and skill but all require payment (Hextrum, 2018b). USRowing, as one example, hosts summer camps for youth development. The camps cost $\$ 3290-\$ 5180$ (USRowing Juniors, 2018). To row for the junior national team, rowers must complete development, identification and selection camps. An athlete who completes the selection process will have paid $\$ 5390$ for fees which excludes travel costs (USRowing, 2018). The NCAA permits athletes to pay to attend private, college, or national team camps. The NCAA also permits universities to profit from camps (NCAA, 2017). Conversely, prospective athletes cannot receive free tuition to camps because this violates the NCAA's definition of amateurism (NCAA, 2017). College coaches endorse these camps both by working at them and by accepting athletes who attended them (Hextrum, 2018b). Thus, athletes with economic capital indirectly purchase physical capital through university and national team camps.

Singer successfully convinced admission committee members that some of his clients were athletes by citing time requirements, private club affiliation, and university and national team camp experience. By accepting these resumes, universities confirmed these markers as evidence of physical capital. Singer's tactics reflect how the athletic admission process permits universities to confirm certain forms of physical capital. Opportunities to develop physical capital are present in all communities and societies (Shilling, 1991). Yet university athletic admissions practices such as elevating pay-to-play camp participation in the evaluation process validates the physical capital associated to white, middle- and upper-class communities.

\section{Social Capital: Connections with University Administrators}

Social capital assumes that social connections translate to favors, action, and opportunities (Bourdieu, 2011). The quality of these relationships and the corresponding favors depend upon one's reputation in the community (Bourdieu, 2011). Harris (1993) also examined how one's reputation furthers property interests. Singer exemplified as much in that he used his reputation to develop social connections within athletic departments to learn the ins-and-outs of recruitment and admission, one form of social capital exchange. This action, in-and-of-itself is not illegal. His operation became illegal when coaches and administrators accepted direct payments from Singer or directed Singer to fund accounts and non-profits they oversaw (Rosen et al., 2019c; Smith, 2019a). College athletic recruitment permits the indirect exchange of social capital for college admission. Pay-to-play clubs and camps, which resided in predominately white suburban areas, provided athletes social ties to nationally and internationally recognized coaches and athletes. These social ties helped athletes navigate recruitment and served as testimonies of one's athletic ability (Hextrum, 2018a, 2018b, 2019). 
In Hextrum (2018a) I argue that while all youth who participate in organized sport are socialized to become athletes, not all athletes are socialized to become college athletes. I framed this different socializing process as "the hidden curriculum of college athlete recruitment" (Hextrum, 2018a). The hidden curriculum refers to practices that "are not readily available, align to advantage certain groups, and are disguised from the public" (Hextrum, 2018a, p. 369). College athletes who had access to families, coaches, and teammates with prior knowledge of and experience with athletic recruitment were at an immediate advantage in the recruitment process. These networks socialized potential athletes in behaviors that would be read favorable by future college recruiters including how to: pursue a less-popular sport; create and execute a marketing campaign; contact college coaches; use "appropriate" etiquette when speaking to recruiters; take unofficial campus visits; and complete athletic questionnaires (Hextrum, 2018a, p. 365). Athletes who used these strategies could underperform on physical capital assessments and still receive admission offers.

Athletes could further supplement their physical capital by using their proximity to reputable coaches as a marker of merit. The NCAA regulates the cost and frequency of interactions between college coaches and potential athletes (NCAA, 2017). The NCAA does not regulate interactions between college and high school coaches. Personal connections between college and high school coaches granted preferential access for certain recruits. I found that "high school coaches leveraged their personal and professional relationships with college coaches to facilitate [college] access" for their current athletes to enhance their program reputations (Hextrum, 2018a, p. 369). Similarly, colleges cultivated extensive social networks with youth coaches to help identify potential recruits. Youth athletes on these programs had an immediate advantage. Several of the rowers and track athletes had high school coaches who went to college with or worked alongside the Coastal-U coaches (Hextrum, 2018a). Nine athletes used their coach's reputation to signify their merit and another eight stated "their [high school] coach 'made a call' on their behalf" to secure admission (Hextrum, 2018a, p. 370). In this way athletes used their coach's reputation and networks to further their own property interest through college access. Further, these legal indirect exchanges are a modern investment in whiteness as universities permit social networking across the high school and college planes that advantage those from white, suburban areas (Hextrum, 2018a, 2018b).

\section{Legitimating Institution: Athletic Admissions}

College athletic admissions reflects the nucleus of whiteness and property because the process is predicated upon the absolute right to exclude (Harris, 1993). Elites, with the consent of the middle-class and Whites, have built an elaborate and exclusive system of higher designed to offer a limited number of slots to students who meet narrow, selective, and subjective criteria (Bourdieu \& Passeron, 1977; Harris, 1993; Khan, 2012; Rivera, 2016; Shamash, 2018; Weis, Cipollone, \& Jenkins, 2014). Bourdieu and Passeron (1977) present college admissions as a legitimating institution through which individuals and families exchange symbolic and material capital for greater educational access. By transforming nebulous cultural markers defined by elites into universally recognized credentials such as admission to a prestigious 
university, college admission maintains rather than disrupts existing power relations. These exchange rates are not transparent nor guaranteed but still legitimate the intergenerational transmission of capital which is then used for greater education and employment access (Bourdieu, 2011).

Singer's scheme erred by creating a transparent and guaranteed form of capital exchange (Smith, 2019a). The FBI made a timeline for each defendant that showed when the direct capital exchange occurred, or how parents transferred funds concurrent to college admission. Those from white, middle- and upper-class communities need not rely upon direct capital exchanges to secure college admission. In the 1978 case Regents of the University of California v. Bakke, the Court ruled universities cannot allocate admission slots based upon race but can allocate slots for student characteristics (e.g. athlete). Whites are allowed to be overrepresented in these preferential slots so long as their access is predicated upon what the law views as the passive absorption of benefits such as living in a de facto segregated white suburb (Harris, 1993). As a result, universities retain the legal right to allocate slots and define the criteria for athletic admission even when said slots and criteria favor white and/or wealthy groups (Harris, 1993; Shulman \& Bowen, 2001).

The student characteristic category of "athlete" is nebulous and favors criteria defined by elites. When universities set aside slots for athletes these policies permit applicants to have grades and test scores below their standard requirements (Shulman \& Bowen, 2001; Smith, 2011). Smith (2019a) explained that "admissions offices at the Universities allot a set number of admission slots to each head coach of a varsity sport for that coach's recruited athletes" (p. 8). The "admission prospects" (the chance of receiving admission) for these applicants are "higher - and in some cases substantially higher" than non-recruited athletes (Smith, 2019a, p. 8). The affidavit notes that Georgetown allots 158 and Wake Forest allots 128 spots per admissions cycle. Coastal-U offered 300 spots. Universities defer to coaches to evaluate athletic merit. The most high-profile defendants in OVB, famed designer Mossimo Giannulli and his wife actress Lori Loughlin, paid Singer and USC $\$ 500,000$ to admit their daughters as rowers. Their daughters' applications falsely claimed they rowed for an exclusive private club located in the expensive housing area of western Los Angeles (Rosen et al., 2019d). My study at Coastal-U demonstrated that such efforts are not required to gain admission in college. In fact, high school students with little-to-no rowing experience were legally admitted as athletes (Hextrum, 2018a).

The discretion offered to coaches in recruitment permits coaches to make a case not only upon an athlete's past merit but on their potential merit. In one study I discussed how White athletes were admitted to college with little-to-no experience in their sport, yet people of color had to over-perform their physical capital to be considered for recruitment (Hextrum, 2018a). In Hextrum (2018a) I contrast the experience of Stella, a White kayaker who had never rowed prior to college but was admitted to an elite school based upon her potential to contribute to a rowing team and Chantae, a Black triple-jumper who had to become a state-ranked high school athlete before coaches would consider her a viable applicant. One excerpt of Stella's recruitment narrative illustrates how the discretion in special athletic admissions can reward white, middle-class applicants. 
Stella never rowed crew but hoped to join a top program based on her athleticism in other sports. She heard through her kayaking teammates-a sport that shares little in common with rowing except water-that college programs would recruit athletes based on potential. Stella viewed the recruiting process as "fake it 'till you make it." To her this meant pretending to be "a big deal — even though I wasn't — I had to make it seem like I was..." She did this through one clever marketing tool: "One of my [kayaking] coaches, she went to the Olympics a lot. So, she wrote me a letter, and I put an Olympic letterhead on it. It looked really cool". Once the Coastal-U coaches were intrigued by Stella's potential, she was invited to meet with them in person. During these interactions, she could "advocate for [her]self" to be admitted to the program (Hextrum, 2019, p. 19).

Stella did not forge her application like those in OVB, but she did embellish her accomplishments. Stella used the symbol of the Olympic rings to signify her potential to become an elite athlete. In this sense, Stella faked her merit by using other indicators such as social connections to excuse their inexperience. Her actions remained legal because her family's economic investments occurred throughout her lifetime rather than a $\$ 500,000$ wire-transfer accompanying an application.

College athletic admissions rely upon the interrelated processes of exclusion (Harris, 1993) and legitimation (Bourdieu \& Passeron, 1997). Higher education utilizes scarcity, particularly at the highly selective universities represented in OVB, to confer greater symbolic and material value to these institutions (Shamash, 2018; Weis \& Fine, 2012; Weis et al., 2014). As white, middle-class members activate their benefits and secure the limited number of spots at elite universities, they simultaneously prevent lower-income and people of color from accruing greater symbolic and material assets. In so doing, white, middle-class members entrench the connections between their communities and the characteristics valued by colleges. In return as fewer and fewer lower-income and people of color access higher education, the characteristics associated with these communities become disconnected from and devalued by colleges (Harris, 1993; Weis \& Fine, 2012; Weis et al., 2014).

\section{CONCLUSION}

OVB positions Singer's actions as perverting legal special admissions in which individuals exchange their athletic talent for university access. Singer's clients lied about their athletic merit and submitted fake awards, honors, and even photoshoppedimages. In prosecuting Singer and his clients, the justice department endorses the current athletic admission process as justly admitting legitimate athletes without capital exchanges. Instead, I argue that OVB enlightens how athletic admissions utilize intangible, nebulous, and subjective definitions of merit that rely upon symbolic capital exchanges and whiteness as property to favor those from white, middle-class communities. These covert forms of capital exchange are legally protected. The celebrity affiliation with and extreme nature of OVB offers a rare cultural moment in which public appetite could be harnessed to create more transparent, accountable, and equitable admission practices. Here, I offer some initial reform suggestions. 
OVB revealed how universities defer to coaches to evaluate and grant admission. Even when schools had an admission form or oversight committee, as was the case with USC, these boards deferred to the coaches' judgement and did not conduct their own independent evaluations of the applicants. My previous research identified how the lack of standardized or publicly available athletic admission processes advantage those from white, middle-class communities. Successfully recruited athletes were embedded in exclusive social communities with knowledge of athletic admissions. Within these communities, athletes learned how to best tailor their recruitment portfolios - in some cases exaggerating their credentials - to secure admission (Hextrum, 2018a, 2018b, 2019). Rather than granting coaches sole discretion, universities should create universal applications and form true oversight committees composed of university staff, faculty, and athletic experts from within and beyond the institution to evaluate the merits of a potential athlete.

OVB also uncovered how athletic admission practices rely upon the absolute right to exclude. Coaches have defined physical capital requirements in ways that align with the white, middle-class communities. U.S. white, suburban, families invest in sports to mark and protect their middle-class standing (Andrews, 1999; DeLuca \& Andrews, 2016; Messner, 2009). Special admissions protect the property interests of Whites by supporting a system predicated upon opportunities for leisure or the rights to enjoyment (Harris, 1993). Through access to leisure activities, Whites are more likely to develop and accrue the physical capital that aligns with the dispositions valued by college recruiters. The athletic resumes used in OVB and in my studies illustrate how costly clubs, national teams, and camps become proxies for physical capital. These criteria were valued by the eight universities named in OVB and are used in the legal process of athletic admission. In this way, athletic admission functions as a legitimating institution through which individuals can exchange their accrued symbolic capital for objective cultural capital in the form of admission to university (Hextrum, 2018b).

More equitable admission processes should incorporate definitions of merit that encompass the broad range of physical capital and cultures. Sport sociologists have shown that youth participate in wide forms of play, game, and physical activity, yet not all forms are recognized by elite athletic organizations like college sports (e.g., Bourdieu, 1978; Coakley, 2015; Sabo \& Veliz, 2008). In creating transparent and publicly scrutinized forms of merit, universities should target a broader range of desirable qualities that do not always align with existing sport forms. For instance, universities should not grant such great weight to pay-to-play sport activities and instead grant greater weight to youth who participate in low-cost or free athletics. I recommend additional research into how universities could create more holistic criteria to identify and select athletes from beyond white, middle-class communities.

Finally, OVB demonstrated how social networks substantiate athletic admission. Legal athletic recruitment permits college coaches to exchange favors within their networks by admitting athletes. High school and club coaches can enhance and protect their reputation by promoting the number of athletes they send to college (Hextrum, 2019). College coaches can receive referrals from high schools and club coaches for potential recruits. There are no processes to monitor how these contacts are made, what favors are promised, and who benefits from these capital exchanges. 
These practices create insular and selective communities with "hidden entry requirements" that reify rather than reduce existing inequalities (Bourdieu, 1978, p. 838). Instead, the NCAA and universities should regulate contacts between coaches across athletic terrains and establish a standardized letter of recommendation to solicit feedback on athletic performance. The recommendations alone will not dismantle the broader legal and entrenched forms of white supremacy and capitalist inequality uncovered by Harris (1993) and Bourdieu (2011). However, they could be a necessary step towards addressing the surreptitious and imbalanced legal process of athletic admissions that further advantages already-advantaged populations.

\section{REFERENCES}

Berry, Alexander, S., \& Steverman, B. (2019, March 29). For an edge in Ivy League admissions grab an oar and row. Bloomberg. Retrieved from https://www.bloomberg.com/news/articles/2019-03-29/for-edge-in-ivy-league admissions-grab-an-oar-and-start-rowing?srnd=premium

Andrews, D.L. (1999). Contextualizing suburban soccer: Consumer culture, lifestyle differentiation and suburban America. Culture, Sport Society, 2(3), 31-53.

Bourdieu, P. (1978) Sport and social class. Social Science Information, 17(6), 819840.

Bourdieu, P. (2011). The forms of capital. (pp. 81-93). In I. Szeman \& T. Kaposy (eds.) Cultural theory: An anthology. Malden, MA: Wiley-Blackwell.

Bourdieu, P. \& Passeron, J.C. (1977). Reproduction in education, society, and culture. Thousand Oaks, CA: Sage.

Coakley, J. (2015). Sport in society: Issues and controversies, (11th ed). New York, NY: McGraw-Hill.

DeLuca, J.R., \& Andrews, D.L. (2016). Exercising privilege: The cyclical reproduction of capital through swim club membership. Sociological Inquiry, 86(3), 301-323.

DiAngelo, R. (2011). White Fragility. International Journal of Critical Pedagogy, $3(3), 54-70$.

Donnor, J. (2005). Towards an interest-convergence in the education of AfricanAmerican football student athletes in major college sports. Race Ethnicity and Education, 8(1), 45-67.

Eckstein, R. (2017). How college athletics are hurting girls' sports. Lantham, MD: Rowman \& Littlefield.

Farrey, T., \& Schreiber, P. (2017, March 17). The gentrification of college hoops.

The Undefeated. Retrieved from

https://theundefeated.com/features/gentrification-of-ncaa-division-1-collegebasketball/

Frances, D., \& Krantz, L. (2019, April 20). College admissions are still easier for the wealthy and well-connected - and it's perfectly legal. The Boston Globe. Retrieved from https://www.bostonglobe.com/metro/2019/04/20/for-wealthymyriad-advantages-college-admissions-even-withoutcheating/oNnMf0BIaekFR5a2jeWGuK/story.html 
Gusa, D.L. (2010). White institutional presence: The impact of whiteness on campus climate. Harvard Educational Review, 80(4), 464-489.

Harris, C.I. (1993). Whiteness as property. Harvard Law Review, 106(8), $1707-$ 1791

Hawkins, B. (2010). The new plantation: Black athletes, college sports, and predominantly White institutions. New York, NY: Palgrave-MacMillan.

Hextrum, K. (2019). Reproducing sports stars: How students become elite athletes. Teachers College Record, 121(4), 1-38.

Hextrum, K. (2018a). The hidden curriculum of college athlete recruitment. Harvard Educational Review, 88(3), 355-377.

Hextrum, K. (2018b). Amateurism revisited: How US college athletic recruitment favors middle-class athletes. Sport, Education, and Society. doi:10.1080/13573322.2018.1547962

Katznelson, I. (2005). When affirmative action was white: An untold history of racial inequality in twentieth-century America. New York, NY: W.W. Norton \& Company.

Khan, S. R. (2012). Privilege: The making of an adolescent elite at St. Paul's School. Princeton, NJ: Princeton University Press

Lartey, J. (2019, March 14). The perfectly legal—but immoral—ways rich kids get into top colleges. The Guardian. Retrieved from https:/www.theguardian.com/us-news/2019/mar/13/rich-kids-top-collegeadmissions

Lapchick, R. (2018). The 2017 college sport racial and gender report card. Orlando, FL: University of Central Florida Institute for Diversity and Ethics in Sport. Retrieved from http://nebula.wsimg.com/5665825afd75728dc0c45b52ae6c412d?AccessKeyId =DAC3A5 6D8FB782449D2A\&disposition=0\&alloworigin=1

Lassiter, M.D. (2012). Schools and housing in metropolitan history: An introduction. Journal of Urban History, 38(2), 195-204.

Llewellyn, M., \& Gleaves, J. (2014). A universal dilemma: The British sporting life and the complex, contested, and contradictory state of amateurism. Journal of Sport History, 41(1), 95-116.

Martin, C. (2010). Benching Jim Crow: The rise and fall of the color line in southern college sports 1890-1980. Urbana: University of Illinois Press.

Mills, C.W. (1997). The racial contract. Ithaca, NY: Cornell University Press.

Mills, C.W. (2003). From class to race: Essays in White Marxism and Black Radicalism. Lantham, MD: Rowman and Littlefield.

Messner, M. (2009). It's all for the kids: Gender, families, and youth sports. Berkeley, CA: University of California Press.

NCAA. (2016). The first in their family. Indianapolis, ID: NCAA. Retrieved from http://www.ncaa.org/about/resources/research/first-their-family

NCAA. (2017). Division-I manual 2017-2018. Indianapolis, ID: NCAA.

NCAA. (2018). Overall Division-I Freshman-Cohort Graduation Rates Report. Indianapolis, ID: NCAA. Retrieved from http://www.ncaa.org/sites/default/files/2016RES_GSR_report_20161114.pdf 
Osburn, S. (2019, October 29). Board of Governors starts process to enhance name, image and likeness opportunities. Retrieved from:

http://www.ncaa.org/about/resources/media- center/news/board-governorsstarts-process-enhance-name-image-and-likeness- opportunities

Ravitch, S.M. \& Carl, N.M. (2016). Qualitative research: Bridging the conceptual, theoretical, and methodological. Los Angeles, CA: Sage.

Rivera, L. A. (2016). Pedigree: How elite students get elite jobs. Princeton, NJ: Princeton University Press.

Rosen, E. S., O’Connell, J. D., Kearney, K.A., \& Wright, L.A. (2019a). United States of America v. Gordon Ernst et al. Federal Indictment Criminal Number 19-CR-10081. https://www.justice.gov/file/1142881/download

Rosen, E.S., O’Connell, J.D., Kearney, K.A., \& Wright, L.A. (2019b). United States v. Toby MacFarlane. Case:19-CR-10131.

https:/www.justice.gov/usao- ma/page/file/1156361/download

Rosen, E.S., O’Connell, J.D., Kearney, K.A., \& Wright, L.A. (2019c). United States v. Gregory Abbott et al. Case:19-CR-10117. https://www.justice.gov/usao-ma/page/file/1152591/download

Rosen, E.S., O’Connell, J. D., Kearney, K.A., \& Wright, L.A. (2019d). United States v. David Sidoo et al. Case: 19-10080-NMG https://www.justice.gov/usao-ma/page/file/1152906/download

Sabo, D. \& Veliz, P. (2008). Go out and play: Youth sports in America. East Meadow, NY: Women's Sports Foundation.

Sack, A. \& Staurowsky, E. (1998). College athletes for hire: The evolution and legacy of the NCAA's amateur myth. Westport, CT: Praeger.

Schneider, J. (2008). Escape from Los Angeles: White flight from Los Angeles and its schools, 1960-1980. Journal of Urban History, 34(6), 995-1012.

Shamash, R. (2018). (Re)production of the contemporary elite through higher education: A review of critical scholarship. Berkeley Review of Education, 8(1), 5-21.

Shilling, C. (1991). Educating the body: Physical capital and the production of social inequalities. Sociology, 25(4), 653-72.

Shulman, J.L., \& Bowen, W.G., (2001). The game of life: College sports and educational values. Princeton, NJ: Princeton University Press.

Smith, L. (2019a). Affidavit in support of criminal complaint. Boston, MA: United States, District Court of Massachusetts. https:/www.justice.gov/file/1142876/download

Smith, L. (2019b). Affidavit in support of criminal complaint for Michael Center. Boston, MA: United States, District Court of Massachusetts. https:/www.justice.gov/file/1142871/download

Smith, R. (2011). Pay for play: A history of big-time college athletic reform. Urbana, IL: University of Illinois Press.

Stephens, N., Hamedani, M. \& Destin, M. (2014). Closing the social-class achievement gap: A difference-education intervention improves first-generation students' academic performance and all students' college transition. Psychological Science, 25(4), 943-953. 
Strauss, A.L., \& Corbin, J. (1998). Basics of qualitative research: Techniques and procedures for developing grounded theory (2nd ed.). Newbury Park, CA: Sage.

Washington, R., \& Karen, D. (2001). Sport \& society. Annual Review of Sociology. 27: $187-212$.

Weis, L., Cipollone, K., \& Jenkins, H. (2014). Class warfare: Class, race, and college admissions in top-tier secondary schools. Chicago, IL: University of Chicago Press.

Weis, L., \& Fine, M. (2012). Critical bifocality and circuits of privilege: Expanding critical ethnographic theory and design. Harvard Educational Review, 82(2), 173-201

KIRSTEN HEXTRUM, PhD, is an Assistant Professor of Educational Leadership and Policy Studies and a faculty affiliate in Women's and Gender Studies at the University of Oklahoma. Email: hextrum@ou.edu 